\title{
Age Determination in the Alpine Accentor Prunella collaris by Discriminant Analysis of Morphological Measurements
}

\author{
Masahiko NAKAMURA \\ Department of Biology, Faculty of Science, Osaka City University, \\ Sugimoto, Sumiyoshi-ku, Osaka 558
}

形態測定值の判別分析によるイワヒバリの年齢判定

\author{
中 村 雅 彦 \\ 大阪市立大学理学部生物学教室
}

Since many behavioural and ecological traits within avian species show age-related effects (e.g. Dhond' 1971, 1989, Harvey et al. 1979, Rohwer et al. 1981, Yamagishi 1981, Komers \& Dhindsa 1989, SAETHER 1990), an essential prerequisite for studies of social organization of a given species is the accurate determination of individual age.

The present paper forms part of a 5-year study of the social organization of the Alpine Accentor Prunella collaris conducted at Mt. Norikura, Japan. This species breeds exclusively in the alpine zone (above $2,600 \mathrm{~m}$ ), and due to the inherent difficulties in observing the birds in such a severe habitat, little is known of the life history of adult birds or the age structure of the population. Up until the end of their first September, juveniles of this species are easily distinguished from adults by their duller plumage (YAmashinA 1941). However, after the post-juvenile molt, yearlings and older birds are indistinguishable in terms of the characters of both plumage colour and wing-coverts (e. g. primary covert tips, see YAMAGISHI 1982).

The size differences between adult and yearling birds are highly significant, and accordingly, for species with no readily visible age-dependent indicators, age is often determined from external morphological measurements (Alatalo et al. 1984, Davies \& Lundererg 1984). However, such morphological measurements usually show considerable overlaps and seasonal variations according to the annual life cycle, e. g. breeding attempt or molting (VAN BAlen 1967, De L aet \& Dhond 1989).

In this paper I investigate age-related variations in eight morphological characters during a restricted sample period and attempt to distinguish yearlings from older ( $\geq 2$-yrold) birds by discriminant analysis using multiple age-related variables.

\section{STUDY AREA AND METHODS}

All studies were performed at the 300-ha summit, of Mt. Norikura, 2,600-3,026 m above sea level, central Honshu, Japan ( $\left.36^{\circ} 06^{\prime} \mathrm{N}, 137^{\circ} 33^{\prime} \mathrm{E}\right)$. At the study area, female Accentors began to lay eggs toward the end of June and molted early in September. In order to exclude any bias from seasonal fluctuations in body size, data collection was restricted within 17 May to 15 June in each year. This period corresponded to pre-breeding season in this population. Throughout the five years of sampling (1985-89), a total of 
172 adult Accentors were captured with a clap net, colour banded and then released at the study site.

Two adult age classes were distinguished: yearlings and older ( $\geq 2$-yr-old) birds. Sex was determined by the form of cloacal protuberance (NAKAmura 1990). During the sample period, 45 older males and 35 older females were captured 51 and 38 times, respectively, while from a total of 198 birds banded as nestlings in 1985- 88 , 38 males and 30 females were recaptured as yearlings 47 and 37 times, respectively. For recaptured individuals, the body size measurement taken on the capture data nearest the mean date of capture for all individuals throughout the sampling periods (17 May-15 June, $\bar{x}=31$ May \pm 9.5 days, $n=173$ captures of 148 individuals) was adopted as the representative body size of that individual.

Morphological measurements followed Svensson (1984). For each individual, eight measurements were recorded: (1) body weight, measured to the nearest $0.1 \mathrm{~g}$ with a beam balance; (2) wing length, the maximum distance from the carpal joint to the tip of the longest primary in the flattened and straightened right wing; (3) tail length; (4) tarsus length; (5) bill length; (6) bill width; (7) bill depth; and (8) head length, the maximum distance from the bill tip to the back of the skull. All linear measurements were taken to the nearest $0.1 \mathrm{~mm}$ with vernier calipers.

Age classes were distinguished by linear discriminant analysis (TANAKA et al. 1984) and the differences between age classes in morphological measurements were statistically analyzed by 2-tailed Student's $t$-test. To evaluate similarities between various size components, the matrix of Pearson's $r$ was generated among the variables.

\section{RESULTS AND DISCUSSION}

Although considerable overlap occurred, older birds showed significantly greater body masses and longer wings and tails than did yearlings. This was true for both sexes (Tables $1,2)$. No age-related increase in size was evident in the five skeletal elements monitored (tarsus length, three bill dimensions and head length, see Tables 1, 2).

Several morphometric studies have noted the value of the wing measurement in age determination (Van Balen 1967, Alatalo et al. 1984, Svensson 1984, Smith et al. 1986) In the Dunnock Prunella modularis, a species congeneric with the Alpine Accentor, Davies \& LUNDBERG (1984) reported that the wing length changes with age and that yearling males have significantly shorter wings than males of two years or older. The present study demonstrated that the Alpine Accentor also displays longer wings in older birds compared with

Table 1. Means \pm 1 S.D. and ranges of 8 measurements of male Alpine Accentors of different age classes (body weight in $\mathbf{g}$; other measurements in $\mathrm{mm}$ ).

\begin{tabular}{|c|c|c|c|c|c|c|}
\hline \multirow{2}{*}{ Measurements } & \multicolumn{2}{|c|}{ Yearling $(n=38)$} & \multicolumn{2}{|c|}{ Older $(n=45)$} & \multirow{2}{*}{\multicolumn{2}{|c|}{$\begin{array}{l}\text { Student's } t \text {-test } \\
\text { (2-tailed) }\end{array}$}} \\
\hline & Mean \pm S.D. & Range & Mean \pm S.D. & Range & & \\
\hline Body weight & $42.2 \pm 2.3$ & $37.0-47.8$ & $45.7 \pm 2.4$ & $41.0-50.4$ & $t=6.95$ & $P<0.001$ \\
\hline Wing length & $100.5 \pm 2.5$ & $90.6-103.6$ & $104.9 \pm 2.3$ & $101.0-109.9$ & $t=8.32$ & $P<0.001$ \\
\hline Tail length & $67.0 \pm 2.1$ & $62.1-70.5$ & $72.9 \pm 2.4$ & $66.8-77.8$ & $t=11.66$ & $P<0.001$ \\
\hline Tarsus length & $27.1 \pm 0.8$ & $25.1-28.6$ & $27.2 \pm 0.8$ & $25.3-28.7$ & $t=0.82$ & n.s. \\
\hline Bill length & $12.9 \pm 0.6$ & $11.5-14.0$ & $13.0 \pm 0.6$ & $12.0-14.4$ & $t=0.99$ & n.s. \\
\hline Bill depth & $5.2 \pm 0.2$ & $4.3-\quad 5.8$ & $5.3 \pm 0.3$ & $4.5-6.0$ & $t=1.60$ & n.s. \\
\hline Bill width & $7.4 \pm 0.4$ & $7.0-8.1$ & $7.5 \pm 0.3$ & $7.0-\quad 8.2$ & $t=1.19$ & n.s. \\
\hline Head length & $38.0 \pm 0.8$ & $35.6-39.5$ & $39.3 \pm 0.8$ & $37.0-40.2$ & $t=1.63$ & n.s. \\
\hline
\end{tabular}


Table 2. Means \pm 1 S.D. and ranges of 8 measurements of female Alpine Accentors of different age classes (body weight in $\mathbf{g}$; other measurements in $\mathrm{mm}$ ).

\begin{tabular}{|c|c|c|c|c|c|c|}
\hline \multirow{2}{*}{ Measurements } & \multicolumn{2}{|c|}{ Yearling $(n=30)$} & \multicolumn{2}{|c|}{ Older $(n=35)$} & \multirow{2}{*}{\multicolumn{2}{|c|}{$\begin{array}{l}\text { Student's } t \text {-test } \\
\quad \text { (2-tailed) }\end{array}$}} \\
\hline & Mean \pm S.D. & Range & Mean \pm S.D. & Range & & \\
\hline Body weight & $37.2 \pm 1.8$ & $33.2-40.8$ & $39.2 \pm 2.0$ & $35.5-43.4$ & $t=4.21$ & $P<0.001$ \\
\hline Wing length & $95.1 \pm 1.8$ & $91.8-99.4$ & $97.7 \pm 1.9$ & $94.0-101.8$ & $t=5.57$ & $P<0.001$ \\
\hline Tail length & $63.7 \pm 2.8$ & $58.5-68.4$ & $66.9 \pm 2.3$ & $62.0-71.2$ & $t=5.06$ & $P<0.001$ \\
\hline Tarsus length & $26.3 \pm 0.7$ & $25.0-27.5$ & $26.5 \pm 0.6$ & $25.0-27.9$ & $t=1.50$ & n.s. \\
\hline Bill length & $12.4 \pm 0.4$ & $11.5-13.3$ & $12.4 \pm 0.6$ & $11.1-14.2$ & $t=0.03$, & n.s. \\
\hline Bill depth & $5.0 \pm 0.2$ & $4.2-5.2$ & $5.0 \pm 0.2$ & $4.4-\quad 5.4$ & $t=0.61$ & n.s. \\
\hline Bill width & $7.2 \pm 0.2$ & $6.9-7.8$ & $7.3 \pm 0.3$ & $6.9-\quad 7.8$ & $t=1.13$ & n.s. \\
\hline Head length & $37.6 \pm 0.5$ & $36.2-38.4$ & $37.8 \pm 0.9$ & $35.0-39.2$ & $t=1.52$ & n.s. \\
\hline
\end{tabular}

yearlings, but a considerable overlap in values was evident (Tables 1, 2).

The discriminating power of using wing length alone was defined using linear discriminant analysis, which revealed that age of only $78.8 \%(67 / 85)$ of males and $73.8 \%(48 / 65)$ of females were identified from this feature. The same method was also applied separately to body weight and tail length measurements, and showed an age-classification success rate of $75.9 \%$ $(63 / 83)$ and $90.4 \%(75 / 83)$ in males, and $75.4 \%(49 / 65)$ and $73.8 \%(48 / 65)$ in females, for body weight and tail length respectively. As such, single variables proved to be of limited use in discriminating between age classes in this study, and therefore multivariate analysis wass ubsequently applied.

Discriminant analysis using the variation of multivariables has the advantages of giving more definite age classification and being statistically more accurate than the univariate method. Actually, this analysis based on external morphological variables has proved to be useful in age or sex determination for some species (SCOLARo 1987, MiLler et al. 1988, Murata et al. 1988, Chardine \& Morris 1989, Harvey IV et al. 1989, K. NAKamura et al. 1989).

Based on the above findings, body weight (BW), wing length (WL) and tail length (TL) were selected as variables suitable for linear discriminant analysis. Five skeletal elements were excluded because there were no significant differences in the size among age classes and thus these elements did not add significantly to the discriminating power of the function. In both sexes, significant correlations were detected among BW, WL and TL (Table 3). In order to examine the influence of multicollinearity and estimate variables that provided the greatest separation of age classes, stepwise discrimenant analysis was performed, and gave the following final functions:

Male: $\quad \mathrm{Z}=0.592 \mathrm{WL}+1.008 \mathrm{TL}-131.330$

Female: $\quad \mathrm{Z}=0.411 \mathrm{BW}+0.504 \mathrm{WL}+0.353 \mathrm{TL}-87.300$

Table 3. Correlation matrix of source data of 3 measurements of males and females.

\begin{tabular}{ccccccccc}
\hline \hline \multirow{2}{*}{ Variable } & \multicolumn{3}{c}{ Male $(n=83)$} & & \multicolumn{3}{c}{ Female $(n=65)$} \\
\cline { 2 - 3 } \cline { 6 - 8 } & BW & WL & TL & & BW & WL & TL \\
\hline Body weight (BW) & - & & & & - & & \\
Wing length (WL) & $0.590^{*}$ & - & & & $0.420^{*}$ & - & \\
Tail length (TL) & $0.625^{*}$ & $0.617^{*}$ & - & & $0.315^{*}$ & $0.520^{*}$ & - \\
\hline
\end{tabular}

$* P<0.01$ 


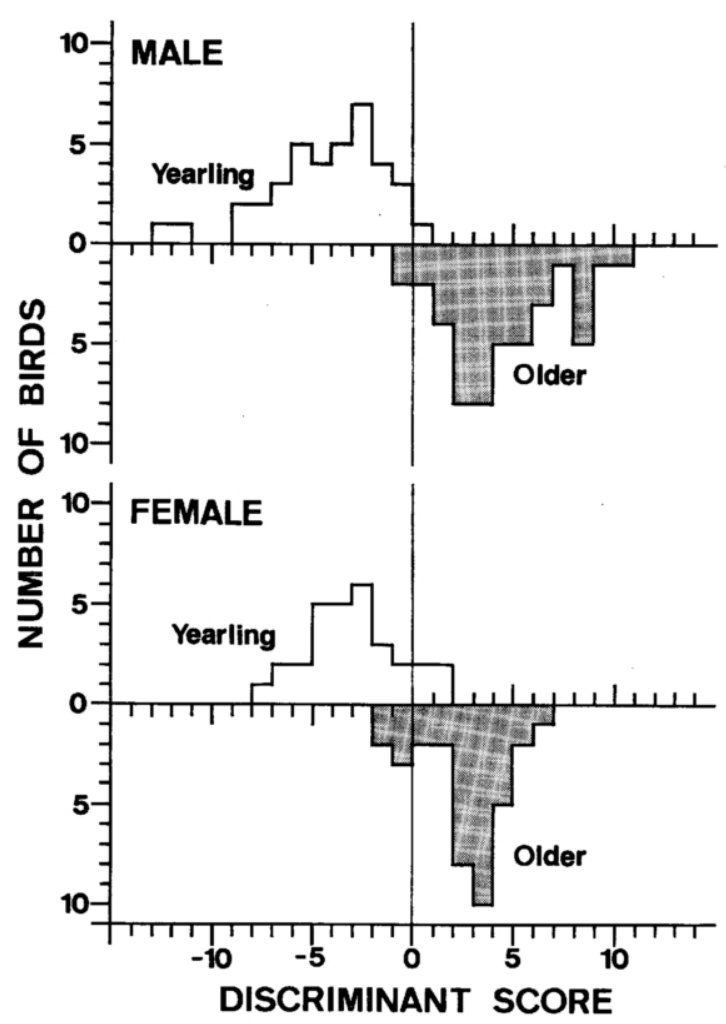

Fig. 1. Frequency distribution of discriminant scores calculated form the final discriminant functions of male (upper) and female (lower) Alpine Accentors.

Age classes were assigned based on the discriminant score $(Z)$, as yearlings when $Z<0$, and olders when $\mathbf{Z}>0$.

Among the three variables, body weight in males was removed due to its non-significant proportion $(F=1.35, d f=1,78, P>0.05)$. The frequency distributions of discriminant scores for all males showed some overlap (overlap zone: $-0.12<Z>0.18$ ), but the resultant function successfully predicted the age classes of $96.4 \%(80 / 83)$ of known-age males; only one of 38 yearlings $(2.6 \%)$ was incorrectly identified as a older, and only 2 of 45 olders $(4.4 \%)$ were incorrectly identified as yearlings (Fig. 1). The difference in covariance between the two age classes was statistically significant $(F=86.97, d f=2,80, P<0.001)$.

The final function successfully classified $86.2 \%(56 / 65)$ of females; 4 yearlings $(13.3 \%)$ and 5 older females $(14.3 \%$ ) were incorrectly classified (Fig. 1). All three variables were selected through the stepwise analysis, and each contributed to the function significantly (BW; $F=$ 5.33, $P<0.05$, WL; $F=7.44, P<0.01$, TL; $F=6.96, P<0.05, d f=1,60$ ). Hence, the final function was not affected by the multicollinearity. The difference in covariance between two age classes was significant $(F=16.97, d f=3,61, P<0.001)$, but the distributions of discriminant scores still overlapped $(-1.52<\mathrm{Z}>1.12)$.

The final function enabled $96.4 \%$ of male, and $86.2 \%$ of female Accentors to be accurately aged; a success rate intermediate between that reported in many species for aging (usually well over $90 \%$; SCOLARo 1987, Miller et al. 1988, HARVEY IV et al. 1989), and much higher than that calculated by discriminant analysis using single variables. However, although 
discriminant analysis based on two or three variables displays greater reliability and objectivity than that based on a single variable, some overlap was still evident in the distributions of discriminant scores for females (Fig. 1). For more accurate age determination of individuals in the zone of overlap, the monitoring of any other indicators is necessary.

\section{ACKNOWLEDGMENTS}

I am greatly indebted to Prof. S. YAmAGishi, Laboratory of Animal Sociology, Department of Biology, Osaka City University, for advice and criticism throughout this study, and to Dr. M. KoHDA and Mr. E. URANo of the same laboratory, for their useful comments on the manuscript. Dr. A. A. ROsSITER improved English and gave valuable comments on earlier drafts of the manuscript. I am also indebted to Prof. T. NAKAMURA, Joetsu University of Education, for continuing guidance and encouragement, and to Mr. K. MURATA and Mr. Y. MATUZAKI for their useful comments and assistance with the fieldwork.

\section{SUMMARY}

1) Linear discriminant analysis was performed on external morphological measurements to distinguish yearling from older ( $\geq 2$-year-old) Alpine Accentors Prunella collaris.

2) From 17 May to 15 June in 1985-1989, morphological variations in eight characters were measured in 148 known-age individuals inhabiting the top of Mt. Norikura, central Honshu, Japan.

3) In both sexes, older birds were significantly heavier and had longer wings and tails than did yearlings, but tarsus length, three bill dimensions and head length showed no increase with age.

4) Stepwise discriminant analysis was performed on body weight (BW), wing length (WL), and tail length (TL). The resultant final functions were as follows:

Male: $\mathrm{Z}=0.592 \mathrm{WL}+1.008 \mathrm{TL}-131.330$

Female: $\quad Z=0.411 \mathrm{BW}+0.504 \mathrm{WL}+0.353 \mathrm{TL}-87.300$

Age classes were assigned based on the discriminant scores ( $Z$ ), as yearlings when $Z<0$, and as olders when $\mathbf{Z}>0$.

5) This analysis proved to be a useful aging method in its reliability and objectivity. By the discriminant function, males and females could be aged in $96.4 \%(80 / 83)$ and $86.2 \%(56 / 65)$, respectively. The classification success rate was much higher than that calculated by the discriminant analysis using a single variable.

\section{摘要}

1）イワヒバリの 1 踰個体と 2 齢以上の個体を判別するため, 複数部位の外部形態測定値に基づく 線形判別分析を行った.

2) 1985-89 年の 5 月 17 日から 6 月 15 日の期間, 乗鞍岳の山頂部に生息し, すでに年跉がわ かっている 148 個体について8 部位の形態を測定した.

3) 雌雄とも 2 齢以上の個体は 1 齡個体に比べ体重は重く, 翼長と尾長も長かったのに対して, 跗 踫長, 嘴峰の 3 部位および全頭長は年龄とともに上昇することはなかった.

4) 体重 $(\mathrm{BW})$, 翼長 (WL) と尾長 (TL) を説明変量に用い変数增減法に基づく判別分析を試み た. その結果, 得られた最終判別式は以下の通りである.

$$
\begin{aligned}
& \text { 雄: } Z=0.592 \mathrm{WL}+1.008 \mathrm{TL}-131.330 \\
& \text { 雌: } Z=0.411 \mathrm{BW}+0.504 \mathrm{WL}+0.353 \mathrm{TL}-87.300
\end{aligned}
$$

年齡クラスは判別值 $(\mathrm{Z})$ より， $\mathrm{Z}<0$ なら 1 齢個体， $\mathrm{Z}>0$ なら 2 齢以上の個体と分類された.

5）判別分析は，信頼性と客観性において有効な年踰査定法であることがわかった. 判別式によっ て, 雄は 95.2\% (78/83), 雌で 86.2\% (56/65) の個体の年齢を判別することが出来た.これらの判 別率はひとつの形態部位の測定值を用いた判別分析による判別率より高かった. 


\section{LITERATURE CITED}

Alatalo, R. V., L. Gustafsson \& A. Lundberg, 1984. Why do young passerine birds have shorter wings than older birds? Ibis 126: 410-415.

Chardine, J. W. \& R. D. Morris, 1989. Sexual size dimorphism and assortative mating in the Brown Noddy. Condor 91: 868-874.

Davies, N. B. \& A. Lundberg, 1984. Food distribution and a variable mating system in the Dunnock, Prunella modularis. J. anim. Ecol. 53: 895-912.

De Late, J. F. \& A. A. DhondT, 1989. Weight loss of the female during the first brood as a factor influencing second brood initiation in Great Tits Parus major and Blue Tits P. caeruleus. Ibis 131: 281-289.

Dhondt, A. A., 1971. Some factors influencing territory in the Great Tit Parus major L. Gerfaut 61: 125-135.

1989. The effect of old age on the reproduction of Great Tits Parus major and Blue Tits $P$. caeruleus. Ibis 131: 268-280.

Harvey, P. H., P. J. Greenwood, C. M. Perrins \& A. R. Martin, 1979. Breeding success of Great Tits, Parus major, in relation to age of male and female parent. Ibis 121: 216-219.

Harvey IV, W. F., G. R. Hepp \& R. A. Kennamer, 1989. Age determination of female Wood Ducks during the breeding season. Wildl. Soc. Bull. 17: 254-258.

Komers, P. E. \& M. S. DHIndSA, 1989. Influence of dominance and age on mate choice in Blackbilled Magpies: an experimental study. Anim. Behav. 37: 645-655.

Miller, S. L., M. A. GregG, A. R. Kuritsubo, S. M. Combs, M. K. Murdock, J. A. Nilsson, B. R. Noon \& R. G. BotZleR, 1988. Morphometric variation in Tundar Swans: relationships among sex and classes. Condor 90: 802-815.

Murata, K., T. Suzuki, M. Yasufuku \& W. Yoshitake, 1988. Sex determination in Manchurian Crane Grus japonensis by discriminant analysis. J. Yamashina Inst. Ornith. 20: 101-106. (In Japanese with English abstract.)

Nakamura, K., F. SAto, F. Sugimori \& T. Imamura, 1989. Sex discrimination based on external morphological measurements in Brown-eared Bulbul Hypsipetes amaurotis. J. Yamashina Inst. Ornith. 21: 253-264. (In Japanese with English abstract.)

NAKAmurA, M., 1990. Cloacal protuberance and copulatory behavior in the Alpine Accentor (Prunella collaris). Auk 107: 284-295.

ROHWER, S., P. W. EWALD \& F. C. RoHWER, 1981. Variation in size, appearance, and dominance within and among the sex and age classes of Harris' Sparrows. J. Field Ornithol. 52: 291-303.

Scolaro, J. A., 1987. Sexing fledglings and yearlings of Magellanic Penguins by discriminant analysis of morphometric measurements. Colon. Waterbirds 10: 50-54.

Smith, J. N. M., P. ArCeSe \& D. Schluter, 1986. Song Sparrows grow and shrink with age. Auk 103: 210-212.

SvensSON, L., 1984. Identification guide to European passerines. 3rd rev. ed. Stockholm.

SAETHER, B. E., 1990. Age-specific variation in reproductive performance of birds. In D. M. POWER (ed), Current ornithology 7: 251-283. New York, Plenum Press.

Tanaka, Y., T. Tarumi, K. Wakimoto \& M. TujtTani, 1984. Handbook of statistics with personal computer programs, II. Multivariate methods: 112-137. Tokyo, Kyoritsu Press. (In Japanese.)

VAN BALEN, J. H., 1967. The significance of variations in body weight and wing length in the Great Tit, Parus major. Ardea 55: 1-59.

YAMAGISHI, S., 1981. Effect of parents' age class on breeding success of the Meadow Bunting Emberiza cioides (Aves: Emberizidae). Jap. J. Ecol. 31: 117-119.

- 1982. Age determination in the Bull-headed Shrike Lanius bucephalus based on buff-tips of greater primary coverts. J. Yamashina Inst. Ornith. 14: 96-102.

YamashinA, Y., 1941. A natural history of Japanese birds 2: 365-367. Tokyo, Iwanami Shoten. (In Japanese.) 